Brit. J. industr. Med., 1954, 11, 296.

\title{
AN INVESTIGATION OF WARTS PREVALENT AMONG WORKERS IN THE REDUCTION WORKS OF THE ALUMINIUM INDUSTRY
}

\author{
BY \\ R. LOCKHART, M.C. \\ From the British Aluminium Co., Ltd. \\ (RECEIVED FOR PUBLICATION OCTOBER 19, 1953)
}

The reduction of alumina to produce the metal aluminium is associated with the manufacture of carbon electrodes for use in electric furnaces containing cryolite and alumina and heated by hydroelectric power. These electrodes, composed of anodes and cathodes, vary in character from blocks to paste, and are made from varying quantities of calcined coke and anthracite mixed with pitch obtained from the distillation of coke oven tar. Workers, therefore, come into contact with pitch dust in the carbon factory or fume in the furnace room to a degree in proportion to the process operated.

In recent years papers have been published stating, or presuming, that the skin of workers exposed to apparently similar hazards was likely to be affected by warts which were, in the opinion of some authors, probably pre-cancerous or even squamous epitheliomata (Fisher, 1953 ; Livingston, 1953). These opinions have naturally led to considerable alarm among both workers and management in this industry, and this investigation was instituted to determine as far as possible (1) whether the handling of pitch in the carbon factory or the exposure to fume in the furnace room is causing an increased incidence of warts among workers intimately exposed to them; (2) whether duration of exposure or service increases the incidence ; (3) the effect of age ; (4) whether the warts found are cancerous or not.

An examination was made of the exposed skin surfaces of a large number of workers in two of the company's reduction works. The number examined was 553 out of 682 in one, and 545 out of 700 workers in the other. They comprised both males and females and the number missed was due to absence from work on examination days, for sickness, or on holiday. The skin surfaces examined were the face, neck, hands, and forearms, which were the parts most exposed to contact with fume and dust. The lesions noted were sessile and pedunculated papillomata, usually small, and all forms of cysts, boils, or other septic foci were disregarded, Barrier creams and goggles were worn by the majority of workers, while gloves were used by certain groups, e.g., paste and certain furnace workers. As both factories are producing aluminium by similar processes and the workers are subjected to similar hazards, the findings for both works have been grouped together.

The employees in each factory were divided into the groups A, B, C, according to intimacy of exposure to the hazard: (A) Continuously in contact, (B) intermittently in contact, and (C) seldom or not at all.

The allocation of workers into these groups was determined not only by my own experience and knowledge of the hazards in the different jobs, but, after consulting with managers and personnel officers, who all had a very long experience of working conditions and who were unbiased as they were not informed as to the reason for my request. The groups were made up as follows :

Group A was composed of men working in jobs involving movement and replacement of anodes on furnaces, and those employed in the handling, breaking up and melting of pitch in the carbon factory.

Group B was composed of men and women employed in a variety of jobs in the furnace room and carbon factory, but not in such close contact with the hazard as those in Group A.

Group C comprised the office staff, power-house workers, and some transport workers and tradesmen, e.g., joiners.

In addition to separating workers into varying 
categories of hazard with the least degree of error, stability of job was also attained to the greatest possible extent. Each group was sharply divided regarding the type of job and wages earned so that change from one group to another seldom occurs, and then only on medical grounds or on leaving the industry.

Group D was a control group made up of 106 men and women of similar age distribution to the factory workers, living in the same locality. They were employed in the hotel industry and in the transport services, and they had never worked in the aluminium factory. Ten of those irdividuals who were garage hands had some contact with mineral oil, but none of the others had a history of contact with any recognized skin hazard.

Similar skin examinations were carried out in each individual, and a note taken of age and duration of service in his or her job. All the examinations were carried out by myself and were, therefore, not subject to varying interpretation of the conditions found.

Later representative warts were excised from each group and submitted to the Pathology Department of Glasgow Royal Infirmary for histological examination and report.

The results of the investigation are set out in Tables $1-5$.

TABLE 1

FREQUENCY OF WARTS IN RELATION TO INTIMACY OF EXPOSURE IN FACTORY AND CONTROL GROUPS

\begin{tabular}{l|c|c|c|c}
\hline Group & $\begin{array}{c}\text { Number } \\
\text { witkbout } \\
\text { Warts }\end{array}$ & $\begin{array}{c}\text { Number } \\
\text { with } \\
\text { Warts }\end{array}$ & Total & $\begin{array}{c}\text { Frequercy } \\
(\%)\end{array}$ \\
\hline A & 70 & 101 & 171 & $\begin{array}{c}59.06 \\
\text { B }\end{array}$ \\
\hline C & 204 & 227 & $\begin{array}{l}431 \\
496\end{array}$ & $\begin{array}{c}52.66 \\
61.09\end{array}$ \\
\hline Total & 467 & 631 & 1,098 & $57 \cdot 46$ \\
\hline $\begin{array}{c}\text { Control } \\
\text { Group D }\end{array}$ & 25 & 81 & 106 & 76.41 \\
\hline
\end{tabular}

TABLE 2

AVERAGE NO. OF WARTS AND \% FREQUENCY IN RELATION TO INTIMACY OF EXPOSURE

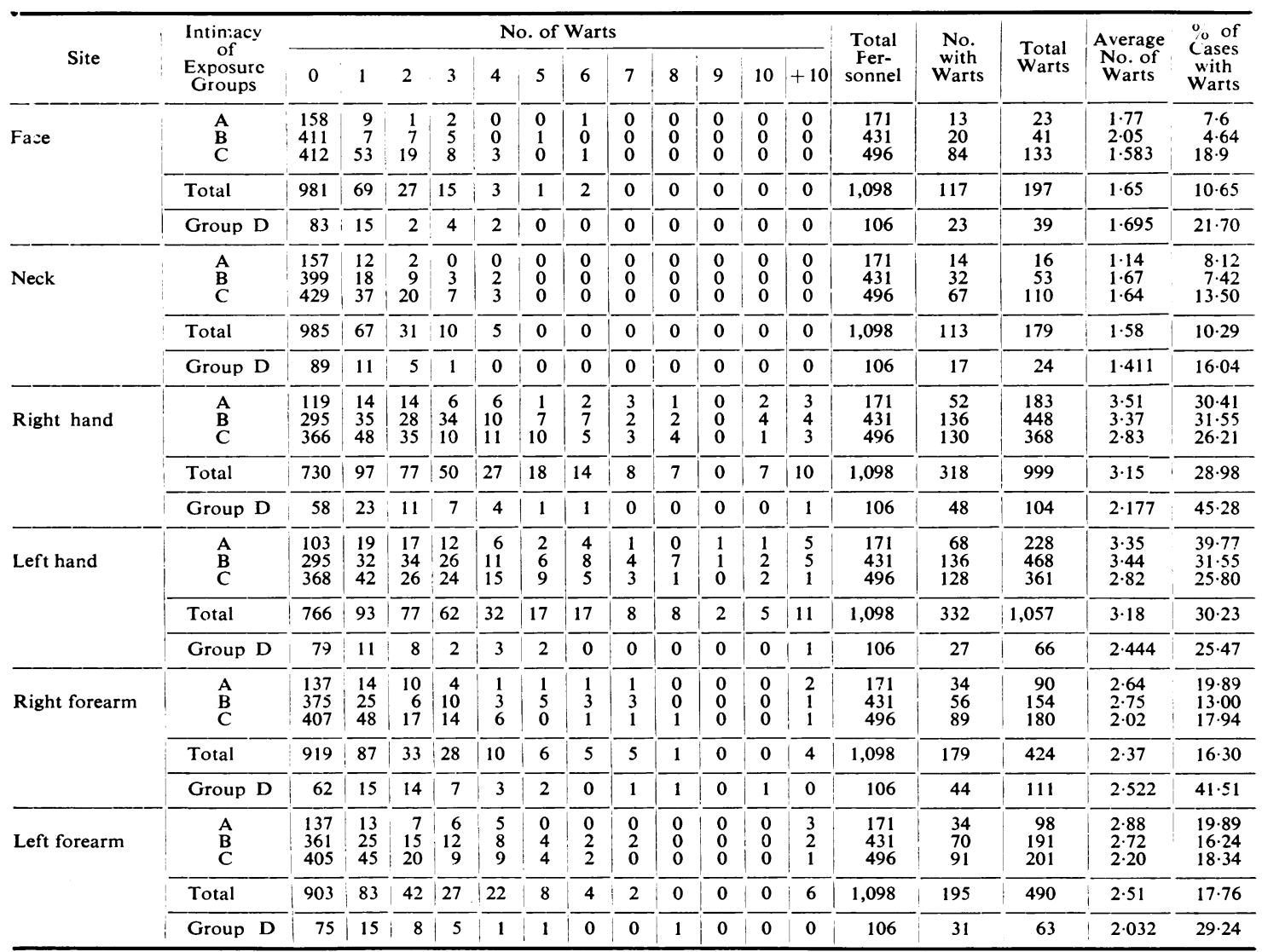


The frequency of warts in group D workers is much higher than in any factory group, while there is no evidence of diminishing frequency from $\mathrm{A}$ to $\mathrm{C}$ Group (Table 1).

Table 2 shows the average number of warts and their frequency of occurrence on the face, neck, hands, and forearms among the factory and control groups.

The frequency for each site is usually higher in the control group except for the left hand, and the frequency in none of the factory groups diminishes regularly with intimacy of exposure except for the left hand. There is a higher frequency in Group A than in Groups B and C on the right and left forearms. There is, however, no regular diminution in frequency with decreasing intimacy of exposure. The highest rate is found in the face and neck in Group $\mathrm{C}$ among the factory workers.

The frequency in relation to both intimacy and duration of service is shown for the factory and control groups in Table 3. In Group B there is a

\section{TABLE 3}

FREQUENCY OF WARTS IN RELATION TO INTIMACY AND DURATION OF SERVICE IN FACTORY AND CONTROL GROUPS

\begin{tabular}{|c|c|c|c|c|c|}
\hline \multirow{3}{*}{$\begin{array}{l}\text { Duration of } \\
\text { Service in } \\
\text { Years }\end{array}$} & \multicolumn{5}{|c|}{$\%$ Frequency and Intimacy of Exposure } \\
\hline & \multicolumn{4}{|c|}{ Factory Groups } & \multirow{2}{*}{$\begin{array}{l}\text { Control } \\
\text { Group D }\end{array}$} \\
\hline & $\mathbf{A}$ & B & C & Total & \\
\hline $\begin{array}{l}0-5 \\
6-15 \\
16+\end{array}$ & $\begin{array}{l}55 \cdot 55 \\
55 \cdot 00 \\
65 \cdot 21\end{array}$ & $\begin{array}{l}46.80 \\
57.75 \\
62.50\end{array}$ & $\begin{array}{l}58 \cdot 29 \\
65 \cdot 11 \\
60 \cdot 17\end{array}$ & $\begin{array}{l}52 \cdot 88 \\
61 \cdot 28 \\
61 \cdot 57\end{array}$ & $\begin{array}{l}73 \cdot 23 \\
88 \cdot 88 \\
62 \cdot 50\end{array}$ \\
\hline Total & $56 \cdot 72$ & $52 \cdot 66$ & 61.09 & $56 \cdot 19$ & 76.41 \\
\hline
\end{tabular}

regular increase in frequency with duration of service which is statistically significant. In Group A the highest rate occurs in the longest exposed group, but there is virtually no difference in the rates of those exposed respectively for none to five years and six to 15 years. In Group $\mathrm{C}$ and control group D the greatest frequency occurs in the middle age group. In the factory as a whole the increase with duration of service is regular but it could have happened by chance; moreover the rates for the controls at individual service lengths are consistently higher than for the factory groups, and as a whole the control rate is nearly half as high again as in the factory groups.

Table 3A shows the frequency of warts for each site separately according to intimacy and duration of service. When all the factory workers together are considered a regular and significant increase of frequency of warts in relation to the length of service is found on both hands and left forearm but it is not found in any of the other sites.
TABLE 3A

FREQUENCY OF WARTS IN RELATION TO BOTH INTIMACY AND DURATION OF EXPOSURE FOR INDIVIDUAL SITES IN FACTORY AND CONTROL GROUPS

\begin{tabular}{|c|c|c|c|c|c|}
\hline \multirow{3}{*}{$\begin{array}{l}\text { Duration of } \\
\text { Service in } \\
\text { Years }\end{array}$} & \multicolumn{5}{|c|}{$\%$ Frequency and Intimacy of Exposure } \\
\hline & \multicolumn{4}{|c|}{ Factory Groups } & \multirow{2}{*}{$\begin{array}{l}\text { Control } \\
\text { Group }\end{array}$} \\
\hline & $\mathbf{A}$ & B & $\mathrm{C}$ & Total & \\
\hline $\begin{aligned} & \text { Face } \\
& 0-5 \\
& 6-15 \\
& 16+\end{aligned}$ & $\begin{array}{r}6.48 \\
5.00 \\
17.39\end{array}$ & $\begin{array}{l}4.25 \\
5 \cdot 17 \\
5 \cdot 00\end{array}$ & $\begin{array}{l}17.06 \\
15.69 \\
20.79\end{array}$ & $\begin{array}{r}9.56 \\
10.67 \\
14.21\end{array}$ & $\begin{array}{l}21 \cdot 12 \\
22 \cdot 22 \\
25 \cdot 00\end{array}$ \\
\hline Total & 7.60 & $4 \cdot 64$ & $17 \cdot 35$ & $10 \cdot 77$ & $21 \cdot 70$ \\
\hline $\begin{array}{l}\text { Neck } \\
0-5 \\
6-15 \\
16+\end{array}$ & $\begin{array}{r}8.33 \\
10.00 \\
4.35\end{array}$ & $\begin{array}{l}8.17 \\
6 \cdot 89 \\
6 \cdot 33\end{array}$ & $\begin{array}{r}14.69 \\
16 \cdot 27 \\
7 \cdot 08\end{array}$ & $\begin{array}{r}10.65 \\
12.19 \\
6.48\end{array}$ & $\begin{array}{l}22 \cdot 53 \\
03.70 \\
00 \cdot 00\end{array}$ \\
\hline Total & $8 \cdot 18$ & $7 \cdot 42$ & $13 \cdot 50$ & $10 \cdot 20$ & $16 \cdot 04$ \\
\hline $\begin{array}{c}\text { Right hand } \\
0-5 \\
6-15 \\
16+\end{array}$ & $\begin{array}{l}25.00 \\
40.00 \\
39 \cdot 13\end{array}$ & $\begin{array}{l}24 \cdot 25 \\
36 \cdot 20 \\
46 \cdot 25\end{array}$ & $\begin{array}{l}23.69 \\
27.90 \\
28 \cdot 31\end{array}$ & $\begin{array}{l}24 \cdot 18 \\
32 \cdot 31 \\
36 \cdot 11\end{array}$ & $\begin{array}{l}45.06 \\
44.44 \\
50.00\end{array}$ \\
\hline Total & $30 \cdot 40$ & $31 \cdot 55$ & $26 \cdot 21$ & 28.96 & $45 \cdot 30$ \\
\hline $\begin{array}{c}\text { Left hand } \\
0-5 \\
6-15 \\
16+\end{array}$ & $\begin{array}{l}35.18 \\
47.50 \\
47.82\end{array}$ & $\begin{array}{l}26 \cdot 80 \\
34.48 \\
41 \cdot 25\end{array}$ & $\begin{array}{l}24 \cdot 17 \\
23 \cdot 25 \\
32 \cdot 74\end{array}$ & $\begin{array}{l}27 \cdot 43 \\
30 \cdot 18 \\
37 \cdot 50\end{array}$ & $\begin{array}{l}22 \cdot 53 \\
33 \cdot 33 \\
25 \cdot 00\end{array}$ \\
\hline Total & $39 \cdot 76$ & $31 \cdot 55$ & $25 \cdot 80$ & $30 \cdot 24$ & $25 \cdot 50$ \\
\hline $\begin{array}{c}\text { Right forearm } \\
0-5 \\
6-15 \\
16+\end{array}$ & $\begin{array}{l}14.81 \\
30.00 \\
26.08\end{array}$ & $\begin{array}{r}6 \cdot 38 \\
18 \cdot 10 \\
25 \cdot 00\end{array}$ & $\begin{array}{l}14.69 \\
25 \cdot 00 \\
13 \cdot 27\end{array}$ & $\begin{array}{l}11 \cdot 19 \\
23 \cdot 17 \\
18 \cdot 98\end{array}$ & $\begin{array}{l}38 \cdot 03 \\
51 \cdot 85 \\
37.50\end{array}$ \\
\hline Total & 19.88 & 12.99 & 17.94 & $16 \cdot 30$ & $41 \cdot 50$ \\
\hline $\begin{array}{c}\text { Left forearm } \\
0-5 \\
6-15 \\
16+\end{array}$ & $\begin{array}{l}15.74 \\
25.00 \\
30.43\end{array}$ & $\begin{array}{r}8.93 \\
22.41 \\
28.75\end{array}$ & $\begin{array}{l}15 \cdot 16 \\
22.09 \\
18 \cdot 58\end{array}$ & $\begin{array}{l}12.53 \\
22.56 \\
23.61\end{array}$ & $\begin{array}{l}22 \cdot 53 \\
44 \cdot 44 \\
37 \cdot 50\end{array}$ \\
\hline Total & 19.88 & $16 \cdot 24$ & $18 \cdot 34$ & $17 \cdot 75$ & $29 \cdot 24$ \\
\hline
\end{tabular}

A similar regular increase in frequency with duration occurs in Group B in the right and left hand and right and left forearm. In none of Groups $A$ or $\mathrm{C}$ in any site does such as increase occur except that which could happen by chance, while in the neck an opposite association is found.

In the control group the only regular increase is found in the face and is not statistically significant. In all other sites no regular association is found with length of service, while a much higher frequency rate is found in all sites than in the factory groups except in the left hand.

Table 4 shows that there is a regular increase in frequency of warts with advancing age for all factory workers and in the control group, whereas for intimacy a similar association occurs only in Group B. In the age groups a diminishing frequency of warts from Groups $\mathrm{A}$ to $\mathrm{C}$ occurs only in the highest age group.

It is noted also that the frequency rates in Group $\mathrm{D}$ are much higher than in any factory group. 
TABLE 4

FREQUENCY OF WARTS AND INTIMACY OF EXFOSURE IN RELATION TO AGE IN FACTORY AND CONTROL GROUPS

\begin{tabular}{|c|c|c|c|c|c|}
\hline \multirow{3}{*}{ Age Groups } & \multicolumn{5}{|c|}{ Frequency of Warts and Intimacy of Exposure } \\
\hline & \multicolumn{4}{|c|}{ Factory Groups } & \multirow{2}{*}{$\begin{array}{l}\text { Control } \\
\text { Group D }\end{array}$} \\
\hline & A & B & $\mathrm{C}$ & Total & \\
\hline $\begin{array}{l}15-35 \\
36-55 \\
56+\end{array}$ & $\begin{array}{r}57 \cdot 14 \\
56.94 \\
100 \cdot 00\end{array}$ & $\begin{array}{l}48.26 \\
55.91 \\
80.00\end{array}$ & $\begin{array}{l}58 \cdot 71 \\
70 \cdot 37 \\
64 \cdot 15\end{array}$ & $\begin{array}{l}54.48 \\
61.66 \\
71.05\end{array}$ & $\begin{array}{r}73 \cdot 75 \\
83.33 \\
100 \cdot 00\end{array}$ \\
\hline
\end{tabular}

Since in Group B the association with age was the most significant, and the correlation of warts with length of service for hands and forearms the most regular, it is necessary to see if this association is related to advancing age or to duration of service.

TABLE 5

FREQUENCY OF WARTS IN GROUP B ACCORDING TO AGE AND DURATION OF SERVICE

\begin{tabular}{|c|c|c|c|}
\hline \multirow{2}{*}{$\begin{array}{l}\text { Duration of } \\
\text { Service in } \\
\text { Years }\end{array}$} & \multicolumn{3}{|c|}{ Age Groups } \\
\hline & $15-35$ & $36-55$ & $56+$ \\
\hline $\begin{array}{l}0-5 \\
6-15 \\
16+\end{array}$ & $\begin{array}{l}43 \cdot 67 \\
39 \cdot 13 \\
50 \cdot 00\end{array}$ & $\begin{array}{l}45.57 \\
64.00 \\
59.67\end{array}$ & $\begin{array}{l}66 \cdot 66 \\
64 \cdot 28 \\
64 \cdot 28\end{array}$ \\
\hline Total & $43 \cdot 17$ & 56.01 & $64 \cdot 51$ \\
\hline
\end{tabular}

Table 5 shows that in each group according to duration of service a regular increase in wart frequency is found with advancing age, whereas in each age group no regular increase in wart frequency is found with increasing duration of service.

\section{Discussion}

The investigation involves contrasts between the control and works groups, and in the works groups an assessment of the association of wart incidence, if any, with intimacy and duration of exposure as well as age to the suspected agent. Owing to the number of workers examined who were representative of various skin types, it is assumed that no single type of individual preponderates, and therefore no assessment of individual type is included. If working conditions, therefore, have an effect on incidence of warts the tabulations should satisfy the following conditions : (1) A diminishing frequency of warts from Groups $A$ to $C$ and a lower frequency in control Group D ; (2) an increasing frequency with length of service ; (3) an increasing frequency with age greater than any normal rise with age.

The contrast between the control and works groups shows a decidedly higher incidence in most sites in the control series than in the works personnel as a whole, or with those workers most intimately and constantly exposed to the suspected agent.

A contrast of the incidence in the three groups of intimacy does not show any relationship, and no tendency for those most intimately exposed to show most warts on any site.

As regards duration of service, most of the groups show irregular and statistically insignificant relationships except in those tabulated. These all show an increase in frequency of warts with duration of service. On the other hand, exactly the opposite relationship seems to obtain in respect of warts on the neck in the intimacy groups as well as in the total. A large proportion of the other sites and many varying groups show no regular increase in frequency for either duration or intimacy of exposure.

In control Group D an increase in frequency with length of time in the job is seen in the face only, and all other sites show an irregular association with generally much higher frequency rates than in corresponding groups in the factories.

Advancing age does show an increase in frequency of warts in Group B and for the factory group totals. The control group, however, also shows a significant association with advancing age. Except for the oldest age group there is no evidence of increasing frequency of warts with intimacy of contact.

The association with the length of time on the job found in the hands and forearms in Group B is in all probability due to the correlation with advancing age rather than to duration of service.

A wart each was excised from six persons representative of the different groups, and of varying lengths of service, and these were sent to Dr. A. R. Currie, of the Department of Pathology at Glasgow Royal Infirmary, for histological examination, as follows :

\begin{tabular}{|c|c|c|c|c|}
\hline $\begin{array}{l}\text { Specimen } \\
\text { No. }\end{array}$ & Name & $\begin{array}{c}\text { Duration } \\
\text { of Employ- } \\
\text { ment } \\
\text { (years) }\end{array} \mid$ & $\begin{array}{c}\text { Type of } \\
\text { Work }\end{array}$ & Group \\
\hline $\begin{array}{l}1 \\
2 \\
3 \\
4 \\
5 \\
6\end{array}$ & $\begin{array}{l}\text { J.S. } \\
\text { M.G. } \\
\text { C.G. } \\
\text { R.B. } \\
\text { R.T. } \\
\text { J.M. }\end{array}$ & $\begin{array}{r}41 \\
11 \\
1 \\
23 \\
15 \\
6\end{array}$ & $\begin{array}{l}\text { Carbon factory } \\
\text { Furnace room } \\
\text { Clerk } \\
\text { Civil engineer } \\
\text { Garage hand }\end{array}$ & $\begin{array}{l}\text { A } \\
\mathbf{A} \\
\mathbf{B} \\
\mathbf{C} \\
\mathbf{C} \\
\mathbf{D}\end{array}$ \\
\hline
\end{tabular}

Dr. Currie was informed beforehand that some of the specimens were excised from individuals working with pitch, but he was unaware of the groups, or of which one was the control. He reported as follows :

" The lesions are all of a similar nature. They are simple papillomatous tumours in which there is hyperplasia of the prickle cell layer but little deepening or broadening of the interpapillary processes. 
Mitotic figures are present in two of the tumours but otherwise they present little evidence of activity. There is little or no melanin pigment in the basal cell layer of the lesions, and there is only a scanty lymphocytic infiltration around the blood vessels in the superficial corium.

"It is not possible to indicate from the histology alone whether the lesions are of an infective nature or due to an exposure to pitch."

The mitotic figures mentioned were present in specimens Nos. 2 and 3 , and in subsequent discussion Dr. Currie stated that they represented evidence of a more rapid growth than in the other warts but of a simple nature only, while it was interesting to note also that it occurred in the men with the shortest duration of service. The most important finding appears to be that the warts examined from Groups $C$ and $D$ presented similar appearances to those in the other groups, and that there is no histological evidence of malignancy in any group.

\section{Conclusions}

Warts prevalent among workers in the reduction works of this industry are, on the sites selected in this enquiry, very frequently found in the general population. We find actually that their frequency is greater in a control group than in the population of the works, where the influence of a carcinogen is suspected. Among the workers there is no strong or regular evidence of association or length of exposure to the presumed agent. Duration of service shows in the instances already mentioned a difference in frequency suggestive of increase with greater length of service, but on other occasions either a reverse association, or no definite relationship at all is found. The influence of age on wart frequency is similar in both the factory and control personnel.

The histological examination shows that the warts from the works groups and the control group are simple papillomata, and that it is not possible microscopically to indicate that these warts are due to pitch, and that in no case was any evidence suggestive of malignancy detected.

The collective evidence of this investigation is consistent with the view that the skin warts observed in the aluminium workers are not produced by an industrial agent.

\section{Summary}

An examination of the exposed skin surfaces of 1,098 out of 1,382 workers in the Aluminium Company's reduction works was carried out, and the number and distribution of warts found are tabulated and discussed.

From the evidence it would appear that the degree of exposure to a presumed carcinogen among workers operating the various processes in the aluminium works is not necessarily productive of cancerous warts.

I wish to thank Dr. A. R. Currie for his kindness in supplying the histological report.

\section{REFERENCES}

Fisher, R. E. W. (1953). Arch. industr. Hyg., 7, 12. Livingston, S. K. (1953). Medical Wld (Lond.), 78, 31.

\section{THE JULY (1954) ISSUE}

The July (1954) issue contains the following papers :-

Some Toxic Properties of Dimethylnitrosamine. By J. M. Barnes and P. N. Magee.

A Report on 235 Cases of Erysipeloid in Aberdeen. By D. M. Proctor and I. M. Richardson.

Raynaud's Phenomenon in Workers with Vibratory Tools. By R. P. Jepson.

The Treatment of Complicated Pneumoconiosis with Isoniazid. By W. E. Miall, P. D. Oldham, and A. L. Cochrane. Silica and Collagen in the Lungs of Silicotic Rats Treated with Cortisone. By B. D. Stacy and E. J. King.

The Development of Compensation for Occupational Diseases of the Lungs in Great Britain. By Andrew Meiklejohn. Tumours of the Urinary Bladder in Workmen Engaged in the Manufacture and Use of Certain Dyestuff Intermediates

in the British Chemical Industry. Part II : Further Consideration of the Role of Aniline and the Manufacture of

Auramine and Magenta (Fuchsine) as Possible Causative Agents. By R. A. M. Case and Joan T. Pearson.

Thermal Conditions in Warships Refitting at H.M. Naval Base, Singapore. By G. Southwell-Sander.

Miscellanea :

Some Personal Observations on Industrial Health in the United States of America. By Bryan Harvey.

Second Conference of the British Occupational Hygiene Society. By R. J. Sherwood.

Obituary :

Edward Provan Cathcart.

Raymond Hussey.

A number of copies are still available and may be obtained from the Publishing Manager, British Medical Association, Tavistock Square, W.C.1, price 12s. 6d. 